\section{Proteasomal regulation of nuclear receptor corepressor-mediated repression}

\author{
Jinsong Zhang ${ }^{1}$ Matthew G. Guenther, ${ }^{1}$ \\ Richard W. Carthew, ${ }^{2}$ and Mitchell A. Lazar ${ }^{1,3}$
}

${ }^{1}$ Departments of M edicine, Genetics, and Biochemistry, University of Pennsylvania School of Medicine, Philadel phia, Pennsylvania 19104 USA; ${ }^{2}$ Department of Biological Sciences, University of Pittsburgh, Pittsburgh, Pennsylvania 15260 USA

Repression of gene transcription is a fundamental property of nuclear hormone receptors. We report here that cell-specific repression by nuclear receptors correlates with levels of nuclear receptor corepressor (N-CoR) protein. $\mathrm{N}$-CoR protein levels are regulated by $\mathrm{mSiah2}$, a mammalian homolog of D rosophila Seven in absentia that targets $\mathrm{N}$-CoR for proteasomal degradation. mSiah2 expression is cell-type specific and differentially regulates the repressive activities of nuclear receptors. These findings establish targeted proteolysis of transcriptional coregulators as a mechanism for cell-specific regulation of gene transcription.

Received January 13, 1998; revised version accepted A pril 17, 1998

Nuclear hormone receptors are among the best studied transcriptional repressors (M angelsdorf et al. 1995; Shibata et al. 1997b). Thyroid hormone receptor (TR) and retinoic acid receptors (RAR) repress transcription in the absence of ligand, thus amplifying the magnitude of Iigand-induced activation (Graupner et al. 1989; Baniahmad et al. 1992). Orphan members of the nuclear receptor superfamily, such as RevErb and COUP-TF, are ligand-independent repressors of transcription (Harding and Lazar 1995; Shibata et al. 1997a). RevErb does not possess the carboxy-terminal amphipathic helix characteristic of ligand-activated receptors, and thus its main function is to constitutively repress transcription. This is likely to serve major developmental roles in a number of organisms; RevErb antagonizes the effects of ROR $\alpha$, whose mutation leads to the cerebellar degeneration of the Staggerer mouse (Hamilton et al. 1996). In Drosophila, the RevErb homolog E75 regulates metamorphosis (Segraves and Hogness 1990; White et al. 1997).

Corepressors N-CoR (nuclear receptor corepressor) and SM RT (silencing mediator of retinoid and thyroid receptors) bind to nuclear receptor di mers and serve as a scaffold for additional proteins involved in repression, including Sin3 and histone deacetylases (Chen and Evans

[Key Words: Nuclear receptor corepressor; proteasomal regulation; repression; RevErb; thyroid hormone receptor; cell specificity]

${ }^{3}$ Corresponding author.

E-MAIL lazar@mail.med.upenn.edu; FAX (215) 898-5408.
1995; Horlein et al. 1995; Alland et al. 1997; Hassig et al. 1997; Heinzel et al. 1997; Nagy et al. 1997). Receptor specificity of corepressor interaction on DNA is exemplified by the observation that RevErb specifically utilizes $\mathrm{N}$-CoR, whereas thyroid hormone receptor TR may use both SM RT and N-CoR to mediate repression (Zamir et al. 1997b).

The amino terminus of $\mathrm{N}-\mathrm{CoR}$ contains two repression domains that have not been identified in the reported sequence of SM RT (Chen and Evans 1995). However, the function of the amino terminus of $\mathrm{N}-\mathrm{CoR}$ has not been well characterized. Here we show that the extreme amino terminus of $\mathrm{N}$-CoR targets the protein for proteasomal degradation because of interaction with mSiah2, the mammalian homolog of Drosophila Seven in absentia (sina). This results in a receptor-specific antirepression function for mSiah2. Expression of $\mathrm{mSiah} 2$ is cell-type specific, explaining the cell specificity of repression by RevErb.

\section{Results and Discussion}

$\mathrm{N}-\mathrm{CoR}$ interacts with mSiah2

To test the hypothesis that the unique amino terminus of $\mathrm{N}-\mathrm{CoR}$ has a regulatory function, amino acids 1-160 were used as bait in a yeast dihybrid screen of a 17-day mouse embryo library. Eleven positive cl ones were identical to mSiah2, a homolog of sina (Carthew and Rubin 1990). The clones (mSiah $2 \Delta \mathrm{N}$ ) began at amino acid 108 of the full-length mSiah2 protein (Fig. 1A). Polypeptides containing $\mathrm{N}-\mathrm{CoR}$ amino acids 1-160 interacted with $\mathrm{mSiah2}$ in yeast, whereas other regions of the amino terminus of $\mathrm{N}-\mathrm{CoR}$ as well as that of SMRT did not (Fig. 1B). The in vivo interaction in yeast was recapitulated in vitro, as a GST fusion of $\mathrm{N}$-COR interacted with in vitrotranslated mSiah2 (Fig. 1C). Although N-CoR amino acids 1-312 interacted with both mSiah2 and mSin3B, amino acids $1-160$ of $\mathrm{N}-\mathrm{CoR}$ interacted strongly with mSiah2 but not with mSin3B. N-CoR (1-312) al so interacted strongly with Sina, whereas the amino terminal repression domain of SMRT did not (Fig. 1D). The ability of $\mathrm{N}-\mathrm{CoR}$ to interact with mSiah2 was also observed in mammalian cells. Consistent with an in vivo interaction, transfected HA-tagged mSiah2 $2 \Delta \mathrm{N}$ coimmunoprecipitated with endogenous N-CoR in 293T cells (Fig. 1E). As this interaction might have occurred in vitro during processing of the cells, we also tested for in vivo interaction using a mammalian two-hybrid assay. Figure $1 \mathrm{~F}$ shows that Gal4-N-CoR(1-160) but not Gal 4-SMRT(1483) was activated by VP16-mSiah $2 \Delta N$, consistent with in vivo interaction between $\mathrm{N}-\mathrm{CoR}$ and $\mathrm{mSiah} 2$.

\section{mSiah2 targets N-CoR for proteolytic degradation}

Both Sina and $\mathrm{mSiah} 2$ have been implicated in regulating proteasomal degradation of certain proteins to which they bind (Hu et al. 1997; Li et al. 1997; Tang et al. 1997). Transfection of $\mathrm{mSiah2}$ with $\mathrm{N}-\mathrm{CoR}$ in $293 \mathrm{~T}$ cells led to 


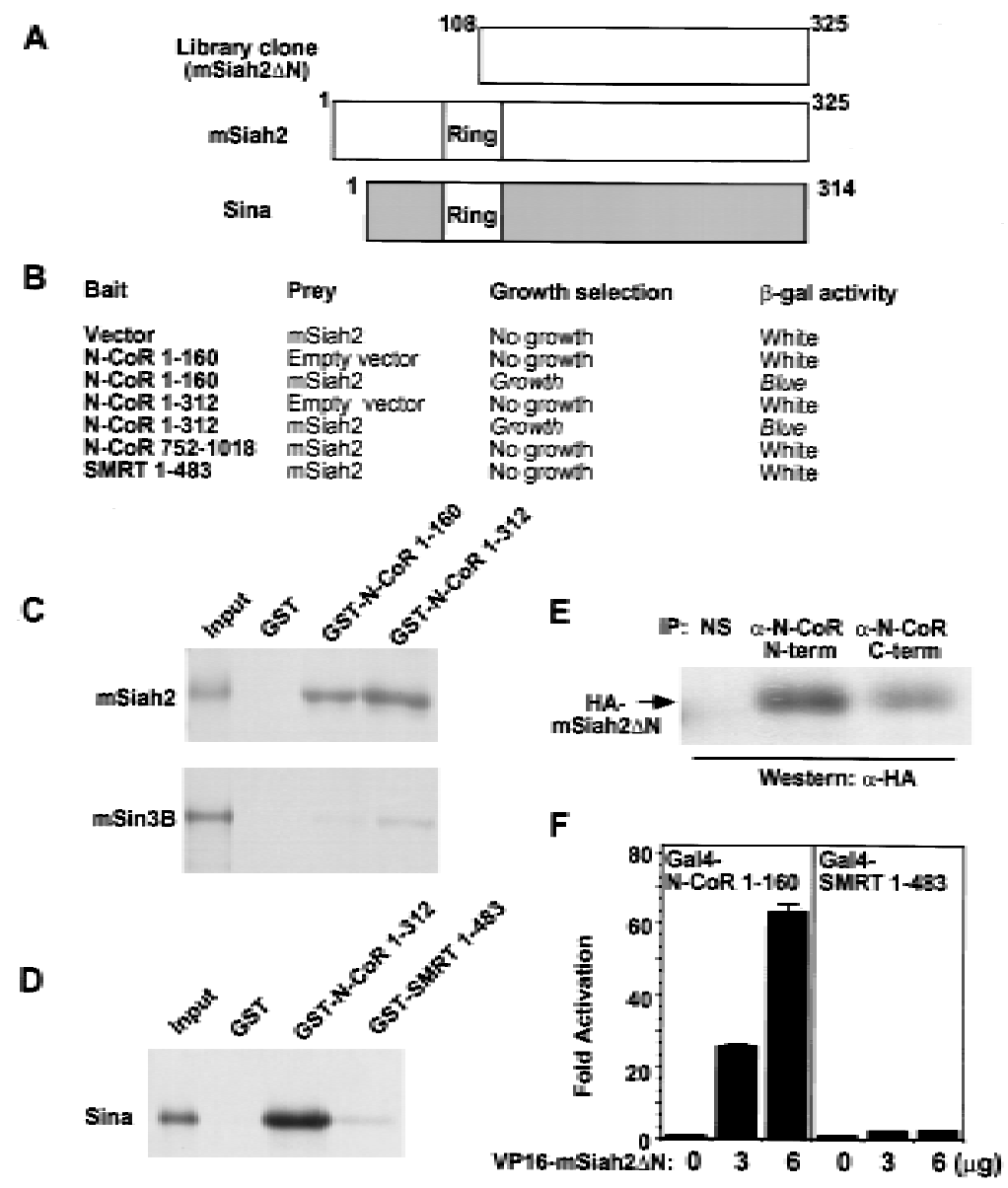

Figure 1. In vivo and in vitro interactions between N-CoR and mSiah2. (A) Comparison of library clone $(\mathrm{mSiah} 2 \Delta \mathrm{N}), \mathrm{mSiah} 2$, and Sina. The location of conserved Ring finger in $\mathrm{mSiah} / \mathrm{Sina}$ is shown. (B) Specificity of interactions between $\mathrm{N}-\mathrm{CoR}$ and $\mathrm{mSiah} 2$ in vivo in yeast. SM RT amino acids 1-483 are homologous to N-CoR(1030-1445). (C,D) In vitro interaction studies using GST-pulldown assay. mSiah2(108-325), Sina, and mSin3B (provided by R. Eisenman, Fred Hutchinson Cancer Research Center, Seattle, WA) were ${ }^{35} \mathrm{~S}$ label ed and translated in vitro. The input lane contained $10 \%$ of total protein. (E) Coimmunoprecipitation of transfected HA-mSiah $2 \Delta \mathrm{N}$ with $\mathrm{N}-\mathrm{COR}$ was performed with nonimmune or rabbit serum containing antibodies raised against $\mathrm{N}-\mathrm{CoR}$ amino and carboxyl termini. The immunoprecipitated protein was visualized by Western analysis with monoclonal $\alpha-\mathrm{HA}$ antibody $12 \mathrm{CA} 5$. (F) Mammalian two-hybrid studies. Interaction between cotransfected Gal4$\mathrm{N}-\mathrm{CoR}(1-160)$ and VP16-mSiah2 $\Delta \mathrm{N}$ as indicated by activation of a luciferase reporter containing a Gal 4 binding site. Gal4 DBD-SM RT(1-483) interacted negligibly with VP16-mSiah2 $\Delta \mathrm{N}$ as shown. Similar results were obtained with Gal4 DBD alone (not shown).

near complete loss of $\mathrm{N}$-CoR protein (Fig. 2A). mSiah2 also markedly reduced levels of $\mathrm{N}-\mathrm{CoR}$ amino acids 1160 fused to Gal 4 DBD, indicating that this effect did not require amino acids $161-2453$ of $\mathrm{N}-\mathrm{CoR}$. The specificity of $\mathrm{mSiah} 2$ for $\mathrm{N}-\mathrm{CoR}$ was demonstrated by its lack of effect on PPAR $\gamma$ (Fig. 2A). Similar results were obtained with cotransfections of $\mathrm{N}-\mathrm{CoR}$ and Sina (data not shown). mSiah2-induced reduction in $\mathrm{N}$-CoR levels was caused by increased degradation of $\mathrm{N}-\mathrm{CoR}$ (Fig. 2B). $\mathrm{mSiah} 2$ reduced the half-life of newly synthesized $\mathrm{N}$ CoR protein from $\sim 14 \mathrm{hr}$ to $\sim 3 \mathrm{hr}$.
The amino terminus of $\mathrm{mSi}$ ah2 2 was required for its ability to target N-CoR protein for degradation, as $\mathrm{mSi}$ ah $2 \Delta \mathrm{N}$ did not lead to inhibition of $\mathrm{N}-\mathrm{CoR}$ expression (Fig. 2C, lane 3). This indicates an active role for a region of mSiah2 that is required for interacting with E2 ubiquitin conjugating enzymes (Tang et al. 1997). The hypothesis that mSiah2 was targeting $\mathrm{N}-\mathrm{CoR}$ for proteolytic degradation via a proteasomal pathway was supported by the observation that the proteasome inhibitor M G132 (Rock et al. 1994) abolished the ability of mSiah2 to reduce levels of $\mathrm{N}-\mathrm{CoR}$ and Gal4-N-CoR(1-160) proteins (Fig. 2C). This indicated that interaction with mSiah2 targeted $\mathrm{N}$-CoR for degradation via a proteasomal pathway.

mSiah2 functions as an antirepressor for nucl ear receptors

The ability of mSiah2 to reduce $\mathrm{N}-\mathrm{CoR}$ protein levels by targeting $\mathrm{N}$-C oR for degradation suggested that mSiah2 should block functional repression caused by N-CoR. RevErb provides an excellent means to test this hypothesis, as $\mathrm{N}-\mathrm{CoR}$ is required for mediating RevErb repression in 293T cells (Zamir et al. 1997b). Both mSiah2 and Sina nearly completely abolished the repression activity of RevErb in 293T cells (Fig. 3A). In contrast, the inability of mSiah $2 \Delta \mathrm{N}$ to block RevErb activity was consistent with its inability to target $\mathrm{N}$ CoR for degradation (Fig. 3B). Both Sina (Fig. 3C) and mSiah2 (not shown) al so blocked repression by Gal4-N-CoR(1-160). Sina had no significant effect on repression mediated by the amino terminal repression domain of SMRT (Fig. 3C). This was expected, as the region of $\mathrm{N}-\mathrm{CoR}$ that interacts with $\mathrm{mSiah} 2 / \mathrm{Sina}$ is absent in fulllength, recombinant SMRT and neither mSiah2 nor Sina interacted with this protein (data not shown). In contrast to its ability to nearly completely abolish repression by RevErb, mSiah2 blocked TR repression by $\sim 50 \%$ (Fig. 3C). This result is consistent with the $\mathrm{N}-\mathrm{CoR}$ selectivity of RevErb, whereas TR may utilize other corepressor(s) as well.

If $\mathrm{N}-\mathrm{CoR}$ degradation was the mechanism by which mSiah2 blocked repression, then MG132, which prevented the mSiah2-targeted proteasomal degradation of $\mathrm{N}-\mathrm{CoR}$, should also prevent mSiah2 from functioning as an antirepressor. The ability of mSiah2 to bl ock the repressi ve activity of RevErb was prevented by treatment with MG132 (Fig. 3D). The protease inhibitor had little or no effect on RevErb repression activity in the absence of mSiah2 transfection (Fig. 3D), suggesting that in 293T cells there was little or no endogenous mSiah2-mediated proteasomal degradation of $\mathrm{N}-\mathrm{CoR}$ in the absence of exogenous mSiah2. 


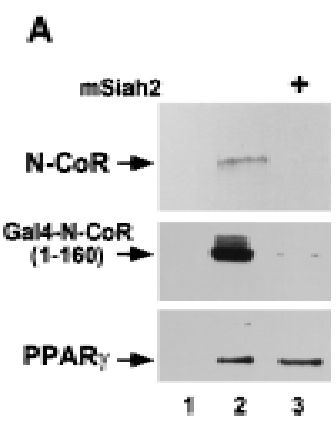

B

C

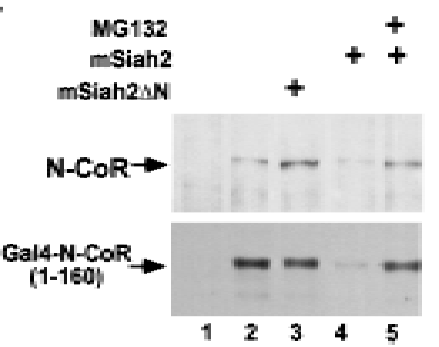

Figure 2. $\mathrm{mSiah} 2$ targets $\mathrm{N}-\mathrm{CoR}$ for proteasomal degradation. (A) $\mathrm{mSiah} 2$ blocks expression of N-CoR in $293 \mathrm{~T}$ cells. Vectors expressing Flag-N -CoR $(20 \mu \mathrm{g}$, lanes 2,3), Gal4-N-CoR(1-160) (20 $\mu \mathrm{g}$, lanes 2,3), and PPAR 2 (10 $\mu \mathrm{g}$, lanes 2,3) or control (lane 1) were transfected into 293T cells with mSiah2 expression vector (lane 3) or control. Gal4-N-CoR and PPAR $\gamma$ were cotransfected. For Flag-N -CoR detection, protein extracts $(200 \mu \mathrm{g})$ were immunoblotted with monoclonal $\alpha$-Flag antibody M2. For Gal4-N-CoR and PPAR $\gamma$ detection, $8 \mu$ g protein extracts were immunoblotted with either antibody to Gal 4 or to PPAR $\gamma$. (B) Half-life of N-CoR determined by pulse chase experiment. Results were quantitated in a PhosphorImager (M olecular Dynamics), normalized to $t=0$ levels, and plotted in semilog format. The level of labeled $\mathrm{N}-\mathrm{CoR}$ at $\mathrm{t}=0$ was reduced in mSiah2-transfected cells, attributable to increased degradation of protein synthesized during the time of the pulse. (C) 293T cells were transfected with expression vectors for indicated proteins and either no N-CoR/Gal4-N-CoR(1-160) (lane 1; top, $300 \mu \mathrm{g}$ protein extract; bottom $29 \mu \mathrm{g}$ extract), or Flag-N -CoR (300 $\mu$ g extract, lanes 2-5, top) or Gal4-N-CoR(1-160) (29 $\mu \mathrm{g}$ extract, lanes 2-5, bottom), and treated with or without MG132 $(20 \mu \mathrm{M})$. Cell extracts were analyzed by immunoblot analysis.

Proteolysis of N-CoR underlies cell specificity of repression

Previously, we observed that RevErb repression varies widely as a function of cell type (Harding and Lazar 1995). Because RevErb utilizes N-CoR as corepressor, we hypothesized that $\mathrm{mSiah} 2$ expression could play a role in this cell-specific repression. mSiah2 mRNA is most abundant in cells of the nervous system that typically express two distinct mSiah2-rel ated mRN As (Della et al. 1993). We found that $293 \mathrm{~T}$ cells contained a single mSiah2 mRNA species, corresponding to the larger of the two reported species. In contrast, N 18 cells contained more of this mSiah2 mRN A and, more strikingly, also contained the second mSiah2 mRNA (Fig. 4A). M oreover, only the $\mathrm{N} 18$ neuroblastoma cells contained detectable levels of mSiah2 protein (Fig. 4B). The N 18 cells contained N-CoR mRNA at levels comparable to those in 293T cells (Fig. 4C). However, consistent with the expression pattern of mSiah2, immunobl ot analysis indicated that N-CoR protein was detectable in 293T cells but undetectable in N 18 cells (Fig. 4D).
The role of regulated $\mathrm{N}-\mathrm{CoR}$ proteolysis in cell specificity of repression was examined by studying RevErb and TR repression activities in the $\mathrm{N} 18$ cells. Unlike non-neuronal 293T cells, and correlating with the expression of mSiah2, RevErb was minimally active in N18 cells (Fig. 5A). Treatment with MG132 dramatically increased endogenous $\mathrm{N}-\mathrm{CoR}$ protein levels in N 18 cells (Fig. 5B), consistent with the hypothesis that endogenous mSiah2 was targeting endogenous N-CoR for proteolytic degradation. Moreover, treatment with the proteasome inhibitor increased RevErb repression activity in $\mathrm{N} 18$ cells by $>8$-fold (from 1.9 - to 16.2-fold, Fig. 5C). Thus, the inability of RevErb to repress gene transcription in N 18 cells was consistent with the expression of mSiah2 and the proteasome-dependent instability of N-CoR protein in these cells. In contrast to RevErb, Figure 5C shows that TR was better able to repress transcription in N 18 cells (mean of 5.9-fold in two experiments). This is consistent with the ability of TR to utilize corepressors other than NCoR, such as SMRT. N evertheless, proteoIytic regulation played a modest role in TR repression, such that MG132 increased TR repression by $\sim 3$ - to 4 -fold (mean of 3.4-fold in two experiments) in $\mathrm{N} 18$ cells.

The putative role of endogenous $\mathrm{mSiah} 2$ in this process suggested that expression of mSiah $2 \Delta \mathrm{N}$, which interacts with $\mathrm{N}-\mathrm{CoR}$ but lacks the ability to target it for degradation, might interfere with interaction be tween N-CoR and endogenous mSiah2, and thus all ow RevErb to function as a repressor in N 18 cells. Consistent with this hypothesis, mSiah $2 \Delta \mathrm{N}$ expression in N18 cells increased RevErb repression to about five fold over basal (Fig. 5D). We note that this is not as dramatic as the effect of proteasomal inhibition. This could be because of insufficient expression of the $\mathrm{mSiah} 2 \Delta \mathrm{N}$, but a more likely explanation is that although interference by $\mathrm{mSiah} 2 \Delta \mathrm{N}$ is competitive, interaction between endogenous $\mathrm{mSi}$ ah 2 and $\mathrm{N}$ CoR is likely to be noncompetitive, because the N-CoR is degraded in a short time frame.

The proteolytic mechanism underlying the function of mSiah2 as an antagonist of $\mathrm{N}-\mathrm{CoR}$ provides a novel mode of regulating transcriptional repression in mammalian cells. Sina was shown recently to bind to a sequence-specific DNA-binding protein, Tramtrack, and target it for degradation through what appears to be a similar pathway (Li et al. 1997; Tang et al. 1997). Sina function in Drosophila involves an additional protein, Phyllopod, which has no known mammalian homolog (Chang et al. 1995; Dickson et al. 1995). Our results indicate that targeting of $\mathrm{N}-\mathrm{CoR}$ degradation in mammalian cells by mSiah2 is either independent of such an activity or due to an endogenous Phyllopod-like activity. 
$\mathrm{N}-\mathrm{CoR}$ and SMRT differ in their abilities to function with different nuclear receptors (Zamir et al. 1997b). mSiah2-directed degradation of N-CoR provides a strategic mechanism for regulating repression in a receptor-specific manner. By preventing N-CoR accumulation, expression of mSiah2 may allow the specificity of SM RT or other putative nucl ear receptor corepressors to dominate in a given cell type, such as the neuroblastoma cells. This regulatory mechanism may be even more general because N-CoR also functions as a corepressor for the transcription factor $\mathrm{Mad}$ (Alland et al. 1997; Hassig et al. 1997; Heinzel et al. 1997) and for the PLZF-RAR $\alpha$ oncoprotein (Grignani et al. 1998; Lin et al. 1998). RevErb is a model for an N-CoR-selective nuclear receptor, and mSiah2 functions as a potent antirepressor in this context. In contrast, repression by TR is only modestly affected by the presence of ectopic or endogenous mSiah2 (in 293T and N 18 cells, respectively). This is consistent with the ability of TR to utilize other corepressors, most notably SMRT. Although recombinant SMRT was not degraded by mSiah2 (data not shown), we cannot rule out the possibility that endogenous SMRT is a target of $\mathrm{mSiah} 2$ and that some other molecule mediates the mSiah2-insensitive repression by TR. Importantly, whereas mSiah2-mediated corepressor proteolysis prevents a subset of repression complexes from forming, this does not prevent nuclear receptor heterodimers from binding to DN A, and the presence of mSiah2 has no effect upon the maximum transcriptional rate of TR in the presence of thyroid hormone (although the fold inducti on caused by hormone is reduced, as the basel ine is not repressed; data not shown).

Cell specificity of transcriptional regulation has been demonstrated for a number of nuclear hormone receptors, as well as other transcription factors. In most cases, the mechanism of cell specificity is unknown. The present work strongly suggests that ubi quitin-mediated proteolysis of $\mathrm{N}-\mathrm{CoR}$ is an important regulator of its function. It is tempting to speculate that si milar regulation of coactivator protein levels might occur. Unlike N-CoR, mSiah2 is not ubiquitously expressed in differentiated mammalian cells, but rather is restricted primarily to cells of the nervous system. Multiple nucl ear receptors that function as repressors are required for normal brain function and development (Forrest et al. 1996; Hamilton et al. 1996; Harding et al. 1997; Qiu et al. 1997). Thus, regulation of $\mathrm{N}-\mathrm{CoR}$ activity by targeted proteolysis is likely to modulate repression in important developmental and functional contexts.

\section{Materials and methods}

Two-hybrid screen

A yeast dihybrid screen of a 17-day mouse embryo library using $\mathrm{N}$ CoR(1-160) as bait was performed as described previously (Zamir et al.
B

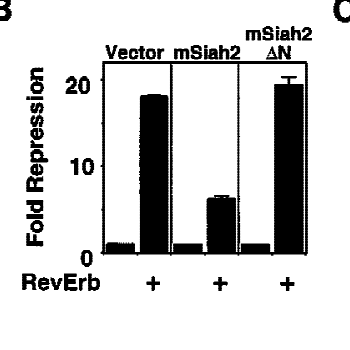

C

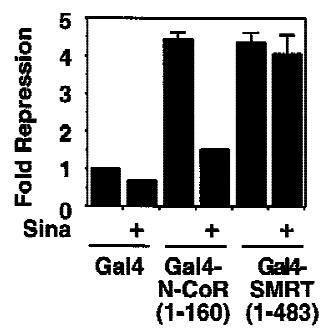

$\mathbf{E}$

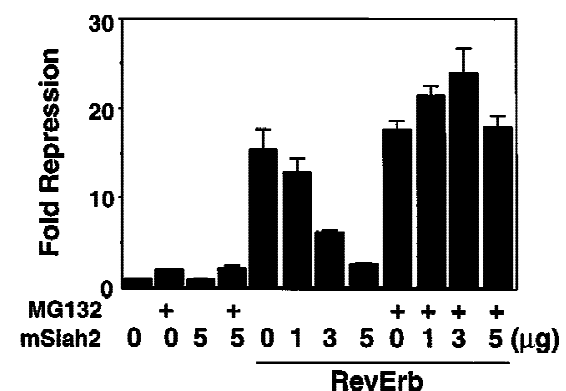

Figure 3. $m S i a h 2$ is a nuclear receptor antirepressor. (A) Transfection of mSiah2 and Sina inhibits RevErb repression in 293T cells. Cells were trans(B) mSiah2 $2 \Delta \mathrm{N}$ does not in $293 \mathrm{~T}$ cells. Five micrograms of mSiah (C) Sina al so functions as antirepressor for Gal4-N -CoR (1-160) but not Gal4483). (D) mSiah2 partially blocks TR repression in 293T cells. Cells repression in 293T cells. mSiah2 inhibits RevErb repression in a concentraon-dependent manner, and this is prevented by treatment with MG132.

1996). The mSiah2 clone obtained multiple times in this screen was not obtained from the same library using at least 10 other baits (Zamir et al. 1996; Cheng et al. 1997).

GST pulldown assays

Input proteins were translated in vitro and labeled with TNT kit (Promega). Preparation of GST fusion proteins and the protein interaction assays were performed as described previously (Zamir et al. 1997b). Bound proteins were eluted by boiling in $30 \mu$ of SDS-PAGE Ioading buffer, resolved by electrophoresis, and visualized by autoradiography. GST fusion proteins were stained with Coomassie blue to ensure equal loading.

\section{Cell culture and transfection}

Expression vectors for RevErb (Harding and Lazar 1993), TR (Zhang et al. 1997), and N-CoR (Horlein et al. 1995) have been described previously. The coding regions of Sina and mSiah2 cDNAs ( $\mathrm{Li}$ et al. 1997) were amplified by PCR and subcloned into pCMX expression vector. Gal 4 and GST fusion proteins were prepared by standard methods and sequenced. Experiments utilizing Gal 4 fusion proteins used (Gal $4 \times 5$ )-SV40-luciferase reporter (Harding and Lazar 1995) except for the mammalian twohybrid experiment in which (Gal4 ×5)-E1B-luciferase was used. 293T and N 18 cells were maintained in DMEM high glucose with $10 \%$ FCS and transfected with calcium phosphate as described previously (Zhang et al. 1997) or in some cases using Lipofectamine reagent (GIBCO) according to manufacturer's instructions. Luciferase activity was normalized to $\beta$-galactosidase activity, which served as an internal control for transfection efficiency. Figures show the results of representative experiments in which individual data points were assayed in duplicate and the mean and range of the results is shown. Each experiment was repeated two to five times. 
Immunoprecipitation and pulse chase

293T cells were transfected with pCMX-Flag-N-CoR and pCMX$\mathrm{mSiah2}$, and label ed for $3.5 \mathrm{hr}$ with ${ }^{35} \mathrm{~S}$-T ranslabel (N EN) $16 \mathrm{hr}$ later after which medium was changed and protein extracts were made at the indicated times and immunoprecipitated as described previously (Zamir et al. 1996) with anti-Flag antibody (Research Diagnostics).

\section{Immunoblotting}

Immunoblotting was performed as described previously (Xue et al. 1996) on 8-400 $\mu \mathrm{g}$ of total protein from 293T or N 18 cells treated with or without 20 M M G132, using antibodies to Gal 4 DBD (Santa Cruz), Flag (Research Diagnostics), PPAR $\gamma$ (Xue et al. 1996), and Sina (Li et al. 1997), as described previously (Harding and Lazar 1995). N-CoR polyclonal rabbit antiserum used for Western and coimmunoprecipitation (" $\alpha$-aminoterminal") was rai sed against N-CoR amino acids 150-425 fused to GST. Carboxy-terminal $\mathrm{N}-\mathrm{CoR}$ antibody used in coimmuniprecipitation was raised against amino acids 1944-2453 fused to GST. N either the aminonor carboxy-terminal $\mathrm{N}$-CoR antibodies immunoprecipitated in vitrotranslated SMRT (not shown). Rabbit antiserum was al so raised against GST-mSiah2. For coimmunoprecipitation, subconfluent 293T cells (100$\mathrm{mm}$ dish) were transfected with $\mathrm{HA}-\mathrm{mSiah} 2 \Delta \mathrm{N}(20 \mu \mathrm{g})$. Coimmunopre cipitation was performed as described previously (Zamir et al. 1997a).

Northern analysis

Poly $(A)^{+}$RNA was purified using the mini-oligo(dT) cellulose spin column (5 Prime-3 Prime, Boulder, CO). N orthern analysis was performed as described previously (Zamir et al. 1997a), with $2 \mu \mathrm{g}$ of RNA for mSiah2 and $3.2 \mu \mathrm{g}$ of RNA for $\mathrm{N}-\mathrm{CoR}$ detection.

\section{A}

\section{B}
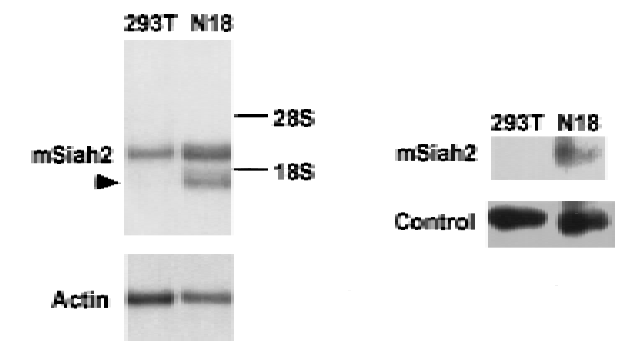

C

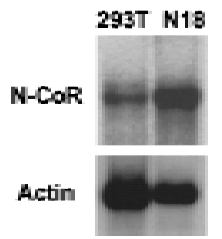

D

Figure 4. Cell specificity of mSiah2 and $\mathrm{N}-\mathrm{CoR}$ expression. $\mathrm{N}$ orthern analysis of mSiah2 (A) and N-CoR (C) mRN A expression. Actin hybridization is shown as loading control. (Arrowhead in A) mSiah2 mRNA species present in N 18 cells and absent from 293T cells. Immunoblot analysis of mSiah2 (B) and $\mathrm{N}-\mathrm{CoR}(\mathrm{D})$ proteins. Total protein (400 $\mu \mathrm{g}$ in B; $200 \mu \mathrm{g}$ in D) was anlayzed, and equal loading and transfer to nitrocellulose was determined by Ponceau S stain (not shown). Rabbit antiserum used was raised against Sina, but similar results were obtained with antisera of lower titer raised against mSiah2. (B, control) Unidentified protein band ( $42 \mathrm{kD}$ ) detected by the Sina antiserum in both $\mathrm{N} 18$ and 293T cells. The mSiah2 band comigrated with the in vitro-translated standard (not shown) at $\sim 36 \mathrm{kD}$. (D, control) Unidentified protein band ( $215 \mathrm{kD})$ detected by the $\mathrm{N}-\mathrm{CoR}$ antiserum in both $\mathrm{N} 18$ and 293T cells. The N-CoR band comigrated with in vitro-translated standard (not shown) at $\sim 270 \mathrm{kD}$
A

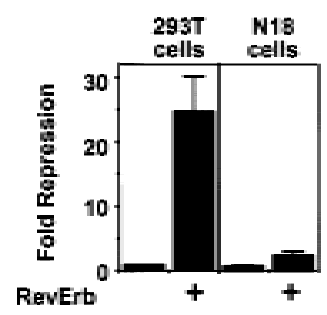

B

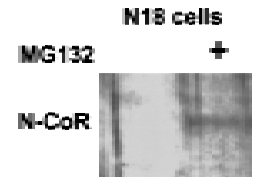

C

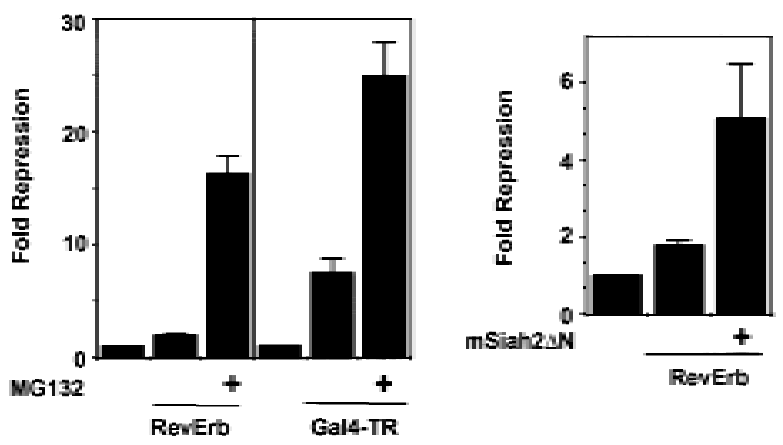

Figure 5. Role of mSiah2-directed proteasomal degradation of $\mathrm{N}-\mathrm{CoR}$ in nuclear receptor repression in N 18 cells. (A) RevErb is a potent repressor in $293 \mathrm{~T}$ but not in N 18 cells. (B) MG132 increases $\mathrm{N}$-CoR protein expression in N 18 cells. Western blot performed as in Fig. 4. (C) Effects of MG132 on repression. (Left) MG132 increases RevErb repression in N18 cells; (right) TR represses in N18 cells, and MG132 potentiates TR repression. (D) $\mathrm{mSiah} 2 \Delta \mathrm{N}$ cotransfection increases RevErb repression in $\mathrm{N} 18$ cells. Three micrograms of $\mathrm{mSiah} 2 \Delta \mathrm{N}$ expression plasmid was transfected.

\section{Acknowledgments}

This work was supported by $\mathrm{National}$ Institutes of Health grants DK43806 and DK45586 to M.A.L. We thank Iris Zamir for help in antibody production and for helpful discussions, and Diane Merry for providing N 18 cells and advice. We also thank Myles Brown and Tom Kadesch for critically reading the manuscript.

The publication costs of this article were defrayed in part by payment of page charges. This article must therefore be hereby marked "advertisement" in accordance with 18 USC section 1734 solely to indicate this fact.

\section{References}

Alland, L., R. Muhle, H. Hou, J. Potes, L. Chin, N. Schreiber-Agus, and R.A. DePinho. 1997. Role for N-CoR and histone deacetylase in Sin3mediated transcriptional repression. Nature 387: 49-55.

Baniahmad, A., A.C. Kohne, and R. Renkawitz. 1992. A transferable silencing domain is present in the thyroid hormone receptor, in the $\mathrm{V}$-erbA oncogene product and in the retinoic acid receptor. EMBO J. 11: 1015-1023.

Carthew, R.W. and G.M. Rubin. 1990. seven in absentia, a gene required for specification of R7 cell fate in the Drosophila eye. Cell 63: 561577.

Chang, H.C., N.M. Solomon, D.A. Wassarman, F.D. Karim, M. Therrien, G.M. Rubin, and T. Wolff. 1995. phyllopod functions in the fate de termination of a subset of photoreceptors in Drosophila. Cell 80: 463-472.

Chen, J.D. and R.M. Evans. 1995. A transcriptional co-repressor that interacts with nuclear hormone receptors. Nature 377: 454-457.

Cheng, X., M.J. Reginato, N.C. Andrews, and M.A. Lazar. 1997. The transcriptional integrator CREB-binding protein mediates positive crosstalk between nuclear hormone receptors and the hematopoietic bZip protein p45/N F-E2. Mol. Cell. Biol. 17: 1407-1416. 
Della, N.G., P.V. Senior, and D.D. Botwell. 1993. Isolation and characterisation of murine homologues of the Drosophila seven in absentia gene (sina). Devel opment 117: 1333-1343.

Dickson, B.J., M. Dominguez, A. van der Straten, and E. Hafen. 1995 Control of Drosophila photoreceptor cell fates by phyllopod, a novel nuclear protein acting downstream of the Raf kinase. Cell 80: 453462.

Forrest, D., E. Hanebuth, R.J. Smeyne, N. Everds, C.L. Stewart, J.M. Wehner, and T. Curran. 1996. Recessive resistance to thyroid hormone in mice lacking thyroid hormone receptor beta; evidence for tissue-specific modulation of receptor function. EMBO J. 12: 30063015.

Graupner, G., K.N. Wills, M. Tzukerman, X.-k. Zhang, and M. Pfahl. 1989. Dual regulatory role for thyroid-hormone receptors allows control of retinoic-acid receptor activity. Nature 340: 653-656.

Grignani, F., S. DeMatteis, C. Nervi, L. Tomassoni, V. Gelmetti, M. Cioce, M. Fanelli, M. Ruthardt, F.F. Ferrara, I. Zamir, C. Seiser, F. Grignani, M.A. Lazar, S. Minucci, and P.G. Pelicci. 1998. Fusion proteins of the retinoic acid receptor- $\alpha$ recruit histone deacetylase in promyel ocytic leukaemia. Nature 391: 815-818.

Hamilton, B.A., W.Y. Frankel, A.W. Kerrebrock, T.L. Hawkins, W FitzHugh, K. Kusumi, L.B. Russell, K.L. Mueller, V. vanBerkel, B.W Birren, L. Kruglyak, and E.S. Lander. 1996. Disruption of the nuclear hormone receptor ROR $\alpha$ in staggerer mice. Nature 379: 736-739.

Harding, H.R. and M.A. Lazar. 1993. The orphan receptor Rev-ErbAo activates transcription via a novel response element. Mol. Cell. Biol. 13: 3113-3121.

-- - 1995. The monomer-binding orphan receptor Rev-Erb represses transcription as a dimer on a novel direct repeat. Mol. Cell. Biol. 15: 4791-4802.

Harding, H.P., G.B. Atkins, A.G. Jaffe, W.J. Seo, and M.A. Lazar. 1997. Transcriptional activation and repression by $R O R \alpha$, an orphan nuclear receptor required for cerebellar development. Mol. Endocrinol. 11: 1737-1746.

Hassig, C.A., T.C. Fleischer, A.N. Billin, S.L. Schreiber, and D.E. Ayer. 1997. Histone deacetylase activity is required for full transcriptional repression by mSin3A. Cell 89: 341-348.

Heinzel, T., R.M . Lavinsky, T.-M . M ullen, M. Soderstrom, C.D. Laherty, J. Torchia, W.-M. Yuang, G. Brard, S.D. N go, J.R. Davie, E. Seto, R.N . Eisenman, D.W. Rose, C.K. Glass, and M.G. Rosenfeld. 1997. A complex containing $\mathrm{N}-\mathrm{CoR}, \mathrm{mSin} 3$ and histone deacetylase mediates transcriptional repression. Nature 387: 43-48.

Horlein, A.J., A.M. N aar, T. Heinzel, J. Torchia, B. Gloss, R. Kurokawa, A. Ryan, Y. Kamei, M. Soderstrom, C.K. Glass, and M.G. Rosenfeld. 1995. Ligand-independent repression by the thyroid hormone receptor mediated by a nuclear receptor co-repressor. Nature 377: 397-404

Hu, G., S. Zhang, M. Vidal, J.L. Baer, T. Xu, and E.R. Fearon. 1997. Mammalian homologs of seven in absentia regulate DCC via the ubiquitin-proteasome pathway. Genes \& Dev. 11: 2701-2714.

Li, S., Y. Li, R.W. Carthew, and Z.C. Lai. 1997. Photoreceptor cell differentiation requires regulated proteolysis of the transcriptional repressor Tramtrack. Cell 90: 469-478.

Lin, R.J., L. Nagy, S. Inoue, W. Shao, W.H. Miller, and R.M. Evans. 1998 Role of the histone deacetylase complex in acute promyel ocytic leukaemia. Nature 391: 811-814.

Mangel sdorf, D.J., C. Thummel, M. Beato, P. Herrlich, G. Schutz, K Umesono, B. Blumberg, P. Kastner, M. M ark, P. Chambon, and R.M Evans. 1995. The nuclear receptor superfamily: The second decade. Cell 83: 835-839.

Nagy, L., H.-Y. Kao, D. Chakvarkti, R.J. Lin, C.A. Hassig, D.E. Ayer, S.L. Schreiber, and R.M. Evans. 1997. N uclear receptor repression mediated by a complex containing SM RT, mSin3A, and histone deacetylase. Cell 89: 373-380.

Qiu, Y., F.A. Pereira, F.J. DeM ayo, J.P. Lydon, S.Y. Tsai, and M.-J. Tsai. 1997. Null mutation of mCOUP-TFI results in defects in morphogenesis of the glossopharyngeal ganglion, axonal projection, and arborization. Genes \& Dev. 11: 1925-1937.

Rock, K.L., C. Gramm, L. Rothstein, K. Clark, R. Stein, L. Dick, D. Hwang, and A.L. Goldberg. 1994. Inhibitors of the proteasome block the degradation of most cell proteins and the generation of peptides presented on MHC class I molecules. Cell 78: 761-775.

Segraves, W.A. and D.S. Hogness. 1990. The E75 ecdysone-induci ble gene responsible for the 75B early puff in Drosophila encodes two new members of the steroid receptor superfamily. Genes \& Dev. 4: 204219.

Shibata, H., Z. N awaz, S.Y. Tsai, B.W. O'M alley, and M.-J. Tsai. 1997a. Gene silencing by chicken oval bumin upstream promoter-transcription factor I (COUP-TFI) is mediated by transcriptional corepressors, nucl ear receptor-corepressor ( $\mathrm{N}-\mathrm{CoR})$ and silencing mediator for retinoic acid receptor and thyroid hormone receptor (SM RT). Mol. Endocrinol. 11: 714-724.

Shibata, H., T.E. Spencer, S.A. Onate, G. Jenster, S.Y. T sai, M .J. T sai, and B.W. O'M alley. 1997b. Role of co-activators and co-repressors in the mechanism of steroid/thyroid receptor action. Rec. Prog. Horm. Res. 52: 141-164.

Tang, A.H., T.P. N eufeld, E. Kwan, and G.M. Rubin. 1997. PHYL acts to down-regulate TTK88, a transcriptional repressor of neuronal cell fates, by a SIN A-dependent mechanism. Cell 90: 459-467.

White, K.P., P. Hurban, T. Watanabe, and D.S. Hogness. 1997. Coordination of Drosophila metamorphosis by two ecdysone-induced nuclear receptors. Science 276: 114-117.

Xue, J.-C., E.J. Schwarz, A. Chawla, and M .A. Lazar. 1996. Distinct stages in adi pogenesis reveal ed by retinoid inhibition of differentiation after induction of PPAR $\gamma$. Mol. Cell. Biol. 16: 1567-1575.

Zamir, I., H.P. Harding, G.B. Atkins, A. Horlein, C.K. Glass, M .G. Rosenfeld, and M.A. Lazar. 1996. A nuclear hormone receptor corepressor mediates transcriptional silencing by receptors with different repression domains. Mol. Cell. Biol. 16: 5458-5465.

Zamir, I., J. Dawson, R.M. Lavinsky, C.K. Glass, M.G. Rosenfeld, and M.A. Lazar. 1997a. Cloning and characterization of a corepressor and potential component of the nuclear hormone receptor repression complex. Proc. Natl. Acad. Sci. 94: 14400-14495.

Zamir, I., J. Zhang, and M.A. Lazar. 1997b. Stoichiometric and steric principles govering repression by nuclear hormone receptors. Genes \& Dev. 11: 835-846.

Zhang, J., I. Zamir, and M.A. Lazar. 1997. Differential recognition of liganded and unliganded thyroid hormone receptor by retinoid $X$ re ceptor regulates transcriptional repression. Mol. Cell. Biol. 17: 68876897. 


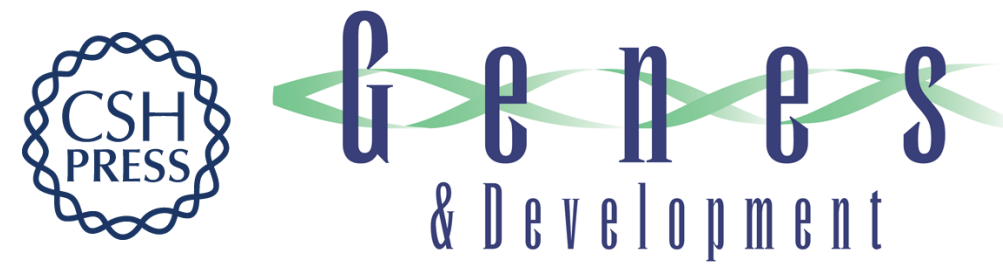

\section{Proteasomal regulation of nuclear receptor corepressor-mediated repression}

Jinsong Zhang, Matthew G. Guenther, Richard W. Carthew, et al.

Genes Dev. 1998, 12:

Access the most recent version at doi:10.1101/gad.12.12.1775

References

This article cites 34 articles, 13 of which can be accessed free at: http://genesdev.cshlp.org/content/12/12/1775.full.html\#ref-list-1

License

Email Alerting

Receive free email alerts when new articles cite this article - sign up in the box at the top Service right corner of the article or click here.

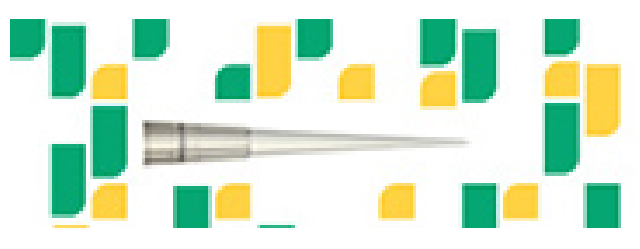

Focused on your science. 